\title{
Team 481 \\ Colorado River Water: \\ Good to the Last Acre-Foot
}




\section{Summary}

The arid region of the Southwestern United States holds one of the most important bodies of water in the nation: the Colorado River, which provides water to nearly 30 million people. The Colorado River Basin has been divided into Upper and Lower Basin regions since the signing of an interstate compact in 1922, and further agreements have specified the amount of water allocated to each state. Lake Powell, the reservoir formed by the Glen Canyon Dam, facilitates the sharing of water between the two basins by providing longterm storage for the Upper Basin's water and water to be sent to the Lower Basin.

With our first model, we develop a simplified geometric model of the shape of Lake Powell to simulate the effects of drought on the volume of the water in the reservoir. We conclude that in the worst-case scenario, when inflow equals $39 \%$ of the historic average, then the lake would run dry in 3.2 years. If inflow equals the probable value of $83 \%$ of the average then the lake's volume would reach about four-fifths of its capacity, and the high inflow of $137 \%$ of the average would yield maximum capacity.

From the second model, we conclude that the Glen Canyon Dam produces more energy if the reservoir is full, and that there is a large difference in the power generated between the three provided scenarios. This is due in part to the height of the reservoir as a direct result of the inflow and also to the fact that the outflow through the dam is dependent on the inflow if the reservoir becomes empty or full.

In our third model, we analyze the agricultural data related to the economy of the states that make up the Basin, examining the correlation between each state's water allocation and its agricultural GSP (Gross State Product). We consider how much water is allocated to each state as a result of the 1922 Compact and how this affects each state's GSP. We finally make recommendations of potential reductions to the amount of water that might be removed from the Colorado River to maintain a minimum capacity in Lake Powell. 
Table of Contents

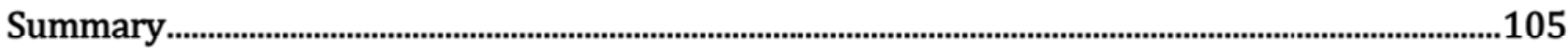

Table of Contents ...................................................................................................................................107

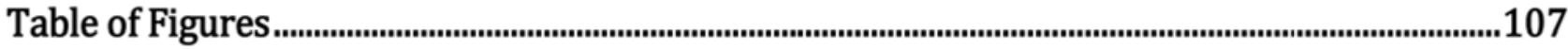

I. Introduction ..............................................................................................................................................108

1. Background of the Situation ...............................................................................................................108

2. Restatement of the Problem ..................................................................................................................110

II. Analysis of the Problem and the Model ......................................................................................110

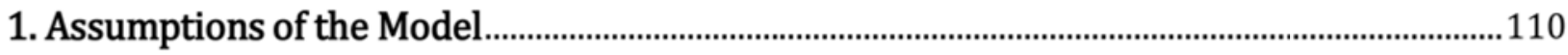

2. Addressing the Problem ......................................................................................................................110

3. Design and Testing of the Models...................................................................................................111

A. First Model: Addressing the Volume of Water in the Lake as a Function of Inflow.........111

B. Second Model: Addressing the Effect of the Height of the Lake on Power Generation..113

C. Third Model: Addressing the Effect of Colorado River Water on the Regional

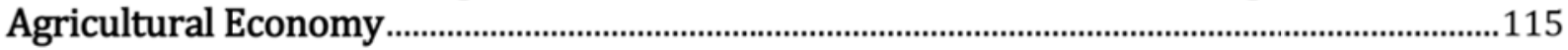

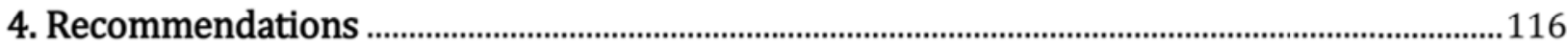

III. Conclusion .............................................................................................................................................................117

Table of Figures

$\begin{array}{lr}\text { Figure 1. } & 108\end{array}$

Figure 2. 110

Figure 3. 116

$\begin{array}{lr}\text { Figure 4. } & 117\end{array}$

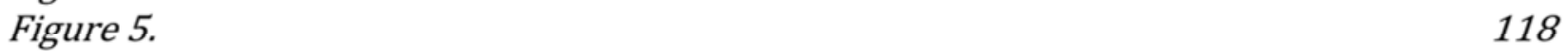

$\begin{array}{lr}\text { Figure } 6 . & 118\end{array}$ 


\section{Introduction}

\section{Background of the Situation}

The Colorado River is one of the most important bodies of water in the United States today. More than 29.3 million people and 4.5 million acres of land in the United States and Mexico rely on the river on a daily basis, as the river provides 10 billion liters of water per day for direct use [9].

A group of laws and regulations collectively referred to as "The Law of the River" governs the distribution of the water. The keystone of the distribution policy is the 1922 Colorado Compact, which divides the region at Lee Ferry between the Upper Basin (Wyoming, Colorado, Utah, and New Mexico) and the Lower Basin (California, Arizona, and Nevada), as pictured in Figure 1. The compact stipulates that each basin should receive an average of 7.5 million acre-feet per year (specifically, it requires that the Upper Basin ensure that the flow below Lee Ferry amounts to at least 75,000,0000 acre-feet over a rolling 10-year period). The compact identifies three main uses for water: domestic use (including household, stock, municipal, mining, milling, and industrial applications), hydroelectric use, and agricultural use [6].

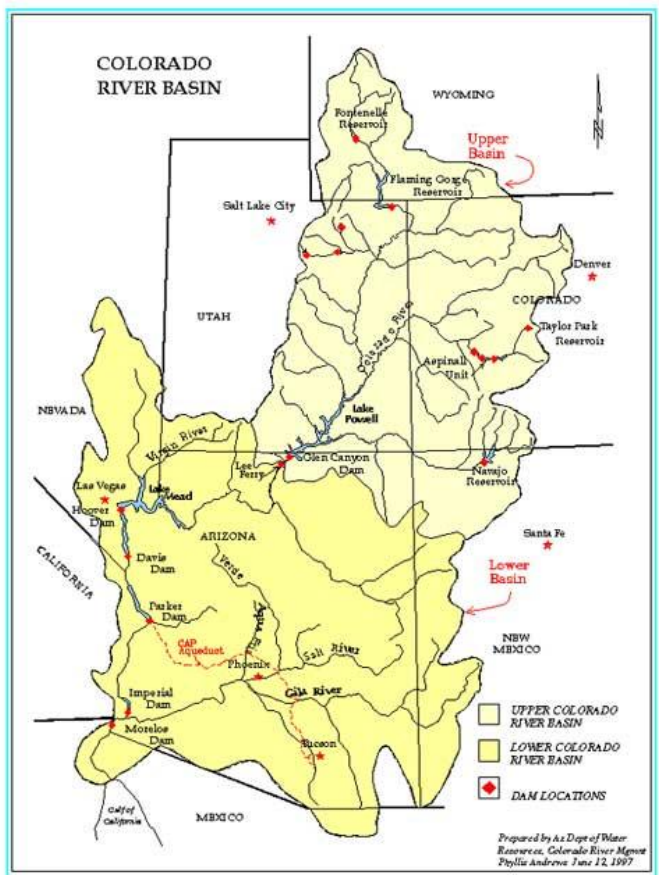

(Figure 1. Map of the Colorado River and the surrounding basin and Compact states, delineating the Upper and Lower Basins) () Arizona Dept. of Water Resources [2]

The Compact also makes provisions for sharing river water with Mexico, stipulating that if the United States chooses to furnish Mexico with water, that water should come from surplus water or, if no such surplus existed, should be drawn equally from the Upper and 
Lower Basins. In 1944, the U.S. ratified a treaty with Mexico that allocated 1.5 million acrefeet, so each basin currently contributes .75 million acre-feet to Mexico [6].

The Boulder Canyon Project Act, which authorized the Hoover Dam and related irrigation facilities in the lower Basin, specifies the amount of water each Lower Basin state should receive: Arizona, 2.8 million acre-feet; California, 4.4 million acre-feet; and Nevada, 0.3 million acre-feet [6].

The Upper Colorado River Basin Compact of 1948 created the Upper Colorado River Commission and specifies the percentage of the Upper Basin's 7.5 million acre-feet each Upper Basin state should receive: Colorado, 51.57\% (3.88125 million acre-feet); New Mexico, $11.25 \%$ (0.84375 million acre-feet); Utah, 23\% (1.725 million acre-feet); and Wyoming, 14\% (1.05 million acre-feet). It also allocates 50,000 acre-feet to the portion of Arizona that lies within the Upper Basin [6].

Construction of the Glen Canyon Dam began in 1956, and on March 13, 1963, two diversion tunnels at the dam were closed to allow Lake Powell to begin filling [13].

Lake Powell plays an important role in the Basin region. The lake serves as a reservoir so that, in times of drought, the water that the Upper Basin is obliged to send to the Lower Basin can come from Lake Powell instead of the Upper Basin states. This system has been working effectively; while inflow has fluctuated throughout the lake's history due to periodic droughts, outflow has been maintained at a minimum of about eight million acrefeet per year (Figure 2) and water users in the Upper Basin have not had to reduce consumption because of Lake Powell's reserved water [6]. In addition, Lake Powell is necessary for generating hydroelectric power at Glen Canyon Dam and farther down the river at Hoover Dam.

Inflow and Outflow of Lake Powell, 1963-2010

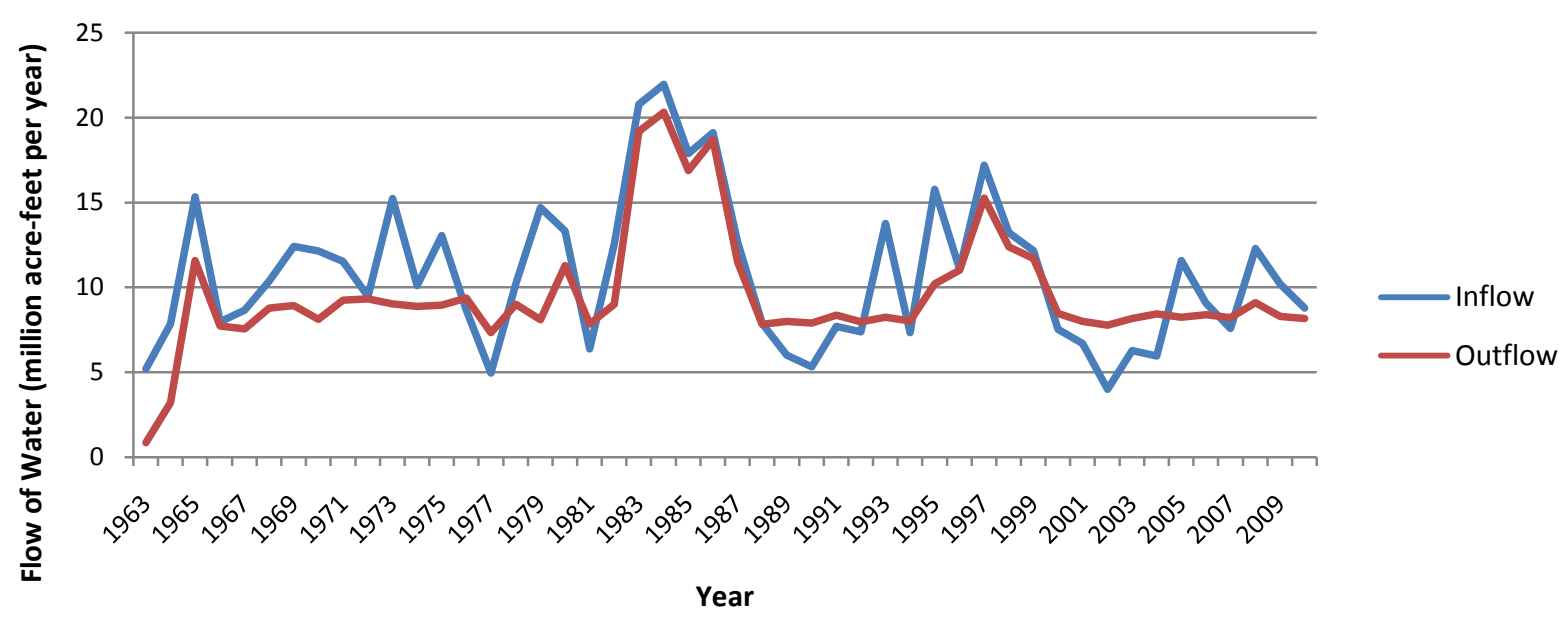

(Figure 2. The annual inflow and outflow of Lake Powell from 1963 to 2010) 
Approximately $80 \%$ of what is left over after $2-3 \%$ of the water in the reservoir evaporates is employed for agricultural ends [1,3]. In fact, irrigation coming from the Colorado River makes the otherwise arid lands surrounding the Lower Basin relatively fertile [9]. This accounts for the high agricultural productivity of the region, which provides the nation with an annual supply of produce. Arizona, which is almost entirely within the bounds of the Basin, contributes $\$ 2.06$ billion dollars of agriculture to the nation's GDP. This revenue is threatened by drought in the Colorado River Basin. Drought, therefore, has a direct effect on the economy of the Lower Basin, the agricultural sector of which uses the water to grow crops to sell and feed to livestock.

\section{Restatement of the Problem}

In modeling the effects of the current drought on Lake Powell, we must examine several significant issues. Our model of Lake Powell's volume at the end of a five-year-period should work for high, low, and probable inflow values. We must consider the drought's implications for the economy of the Lower Basin, including hydroelectric power generation, and we must seek water-saving strategies to reduce outflow so that we can maintain at least a minimum volume.

\section{Analysis of the Problem and the Model}

\section{Assumptions of the Model}

The following conditions will be assumed to be true throughout this analysis:

1. The efficiency of dam is assumed to be a constant, which is calculated for the second model.

2. The average inflow rate of Lake Powell is 12.0 million acre-feet per year. A longterm drought has brought the lake's capacity to $60 \%$ and the estimated future inflow ranges from an average $39 \%$ low to an average $137 \%$ high, with an $83 \%$ standard average.

3. For modeling purposes, the shape of the lake will be assumed to be conical. (See "Design of the Model.")

4. The pressure of the water absorbed in the rocks below the Lake Powell reservoir is proportional to but less than the pressure of the water in the lake itself; this can be assumed because in areas where there is more pressure from the lake, more water would have seemed into those rocks, and likewise for areas with less pressure.

\section{Addressing the Problem}

In our first model, we predict the volume of Lake Powell over the next five years based on the assumed inflow and expected outflow.

With our second model, we assess the effects of the current drought on hydroelectric power production at Glen Canyon Dam over a five-year range. 
In our third model, we consider the harmful effects of drought on the economy.

\section{Design and Testing of the Models}

\section{A. First Model: Addressing the Volume of Water in the Lake as a Function of Inflow}

The rate of change in volume in the reservoir is equal to the inflow minus the water leaving the reservoir from all sources: evaporation, seepage, and outflow. Thus, we let $V(t)$ be the volume of the reservoir, $I(t)$ be the inflow, $E(t)$ be the rate of evaporation, $S(t)$ be the rate of seepage, and $O(t)$ be the outflow through Glen Canyon Dam. Therefore, $\frac{d V}{d t}=I(t)-$ $[E(t)+S(t)+O(t)]$.

Due to the series of agreements described above, at least 82.3 million acre-feet must be sent through the dam every ten years. We will assume that an average amount -8.23 million acre-feet per year, or 10.1516 billion cubic meters per year - of water will be released; thus $O(t)=1.01516 \times 10^{10}$ cubic meters per year.

The maximum depth of the Lake Powell is 170 meters, and the mean depth is approximately 40 meters [12]. Therefore, the lake's depth ratio, defined as the mean height divided by the maximum height, is $\frac{4}{17} \approx 0.235$. The mean height multiplied by the base area of a solid equals the volume, so depth ratio $=\frac{\text { volume }}{\text { base area } \times \text { maximum height }}$. A hyperboloid surface has a depth ratio between $\frac{1}{3}$ and $\frac{1}{2}$, a paraboloid has a depth ratio of $\frac{1}{2}$, and an ellipsoid has a depth ratio between $\frac{1}{2}$ and $\frac{2}{3}$ [7]. By contrast, a cone has a depth ratio of $\frac{\frac{1}{3} \pi r^{2} h}{\left(\pi r^{2}\right)(h)}=\frac{1}{3}$. A sinusoid can have a depth ratio as small as 0.297 [7]; however, this is only a small reduction and is not worth the complexity of sinusoidal models.

Lake Powell has a capacity of $2.6526 \times 10^{10}$ cubic meters and a surface area of 65,843 hectares [12], or $6.5843 \times 10^{8}$ square meters, so it has an average height of $\bar{h}=$ $\frac{2.6526 \times 10^{10}}{6.5843 \times 10^{8}} \approx 40.287$ meters. Because the maximum height is three times the average height, the maximum height of the reservoir is $3 \bar{h}=120.86$ meters. Note that this is significantly less that the true maximum value of 170 meters; an unusually deep part of the reservoir could account for this difference.

In a cone, the radius of any cross-section is proportional to the distance of that crosssection from the vertex, so the area of a cross-section is proportional to the square of this distance, or $A=h^{2} k_{1}$ for some constant $k_{1}$. Note that $k=\frac{A}{h^{2}}=\frac{6.5843 \times 10^{8}}{(120.86)^{2}}=45075.73$, so $A=45075.73 h^{2}$, or $h=\sqrt{\frac{A}{45075.73}}=\frac{\sqrt{A}}{212.310}$ regardless of the values of $A$ and $h$. 
Furthermore, $V=\frac{1}{3} \pi r^{2} h=\frac{1}{3} A h=\frac{1}{3}\left(\frac{\sqrt{A}}{212.310}\right) A=\frac{A^{\frac{3}{2}}}{636.931}$. Rearranging gives us $A=$ $(636.931 V)^{\frac{2}{3}}$

Because evaporation can only occur at the surface of a liquid, the rate of evaporation is assumed to be proportional to the surface area of the lake. In water year 1997 (from 1 Oct. 1997 to 30 Sept. 1998), 587,000 acre-feet, or $7.2405 \times 10^{8}$ cubic meters of water were lost to evaporation [4]. In this year, the volume of Lake Powell was 21385702.44 acre-feet $\left(2.63794 \times 10^{10}\right.$ cubic meters $)$, so the surface area was $6.5599 \times 10^{8}$ square meters. Thus, the rate of evaporation per square foot of surface area is $\frac{7.2405 \times 10^{8}}{6.5599 \times 10^{8}}=1.10375$ meters per year. We ignore seasonal variation in evaporation rate because we are concerned about long-term trends rather than short-term fluctuations.

The combined rates of seepage and evaporation have averaged 860,000 acre-feet (1.06079 $\times 10^{9}$ cubic meters annually) [18]. Based on volume data [17] and our model, the average surface area of the lake over the past twenty years (1991-2010) has been $542,999,596.2$ square meters. Thus, the average rate of evaporation has been $(542,999,596.2)(1.10385)=5.99391 \times 10^{8}$ cubic meters per year. It follows that, on average, the remaining $1.06079 \times 10^{9}-5.99337 \times 10^{8}=4.61457 \times 10^{8}$ cubic meters per year was lost due to seepage.

By Darcy's Law, the rate of seepage through a specific area is proportional to the pressure difference between the lake and the rocks below [5]. Thus, the total seepage is proportional to $\iint_{R} P_{\text {lake }}-P_{\text {rocks }} d A$, where $P$ is the pressure and $R$ is the region covered by the lake. Because we are assuming that the water pressure in the rocks is proportional to the water pressure in the lake, and water pressure is proportional to height $(P=\rho g h)$, the rate at which water seeps out of the lake is proportional to $\iint_{R} h d A$, which equals the lakes volume; thus, $S(t)=V(t) k_{2}$. The average volume over the twenty-year period 1991-2010 was $2.00729 \times 10^{10}$, so the seepage constant $k_{2}$ is equal to $\frac{4.61457 \times 10^{8}}{2.00729 \times 10^{10}} \approx 0.0230033$.

Finally, $I(t)$ is a constant, which we will call $I$. We are asked to test the model with $I$ equal to $39 \%, 83 \%$, and $137 \%$ of the historical average of 12.0 million acre-feet per year.

We can now write the differential equation for the water in the reservoir:

$$
\begin{gathered}
\frac{d V}{d t}=I(t)-[E(t)+S(t)+O(t)] \\
\frac{d V}{d t}=I-1.10375 A-0.0230033 V-1.01516 \times 10^{10}
\end{gathered}
$$

Because $A=(636.931 V)^{\frac{2}{3}}$, we have

$$
\frac{d V}{d t}=I-81.7084 V^{\frac{2}{3}}-0.0230033 V-1.01516 \times 10^{10}
$$


We now examine each of the three cases using $V(0)=1.56927 \times 10^{10}$ cubic meters of water, corresponding to the volume of water in the lake on 17 April 2011 [17]. The values of the low, most likely, and high estimates of inflow are $5.77270 \times 10^{9}, 1.22855 \times 10^{10}$, and $2.02784 \times 10^{10}$ cubic meters per year, respectively. We now solve the differential equation using a Runge-Kutta method by letting $V_{n+1}=V_{n}+x \frac{f\left(t_{n}, V_{n}\right)+f\left(t_{n+1}, V_{n}+x f\left(t_{n}+V_{n}\right)\right)}{2}$ [20], where $f(t, V)=\frac{d V}{d t}$, and step size $x=0.001$. Because the primary contributors to $\frac{d V}{d t}$ are $I$ and $-1.01516 \times 10^{10}$, both of which are constants, decreasing $x$ would not significantly change the results.

In the low estimate, the reservoir would empty within 3.233 years. In the most likely estimate, the reservoir's water would increase to $2.1353 \times 10^{10}$ cubic meters, about $80.50 \%$ of the lake's capacity. In the best-case scenario, the reservoir would reach its maximum capacity of $2.6526 \times 10^{10}$ cubic meters in 1.202 years.

To determine the effect of a small increase in water inflow, we increase the most probable scenario's inflow to $83.83 \%$ of the historic average, or $1.24083 \times 10^{10}$ cubic meters per year. In this scenario, the lake's volume would increase to $2.1906 \times 10^{10}$ cubic meters, or $82.58 \%$ of the lake's capacity. Thus, the change in the lake's volume would be $6.21 \times 10^{9}$ cubic meters over the five-year period, compared to an increase of $5.66 \times 10^{9}$ cubic meters assuming an inflow of $83 \%$ of the historic average. Because these values for the increase in water differ by $9.76 \%$ and the inflows differ by only $1 \%$, our model for the volume of the lake is quite sensitive.

\section{B. Second Model: Addressing the Effect of the Height of the Lake on Power Generation}

An electrical generating plant converts the potential energy of water stored by the reservoir into electrical energy. If a certain mass drops a distance $d$, the potential energy lost by the mass is $m g d$ (where $g=9.8 \mathrm{~m} / \mathrm{sec}^{2}$ ). Because one cubic meter of water has a mass of roughly 1000 kilograms, we can rewrite this expression for the total potential energy lost annually as $98000 d$ joules, where $d$ the drop in height (in meters) and $O$ is the outflow of water through the dam (in cubic meters per year). The Glen Canyon Dam has a hydraulic height of 579 feet [6], or 176.4792 meters, so the water falls 176.4792 meters if the reservoir is fully filled. This value is 55.619 meters greater than the height of the reservoir, so we can further expand this expression to $98000(h+55.619)$ joules. Because the maximum height equals $\frac{3 V}{A}=\frac{3 \mathrm{~V}}{(636.931 V)^{\frac{2}{3}}}=\frac{\sqrt[3]{V}}{24.676}$, we can write the total loss in annual potential energy is $9800(O)\left(\frac{\sqrt[3]{V}}{24.676}+55.619\right)$ joules. The electrical generating plant loses some energy to friction and seepage through the dam, so its efficiency is not $100 \%$. We will assume that this efficiency is a constant $e$, so the total electrical energy generated is $9800(0)\left(\frac{\sqrt[3]{V}}{24.676}+55.619\right)$ e. However, electrical energy is usually measured in kilowatthours, and 1 kilowatt-hour equals 3.6 million joules ( 1 joule $=1$ watt-second), so we divide 
this expression by 3.6 million to obtain $E=\frac{49}{18000} O e\left(\frac{\sqrt[3]{V}}{24.676}+55.619\right)$, where $E$ is measured in kilowatt-hours per year.

In fiscal year 2007 (which, like the water year, lasts from October 2006 to September 2007), the power plant generated 3,454,846,789 kilowatt-hours of electricity [6]. In water year 2007, the reservoir volume was $1.47821 \times 10^{10}$ cubic meters and the outflow was 11366.02 cubic feet per second, or $1.01516 \times 10^{10}$ cubic meters per year. Thus, we have $3,454,846,789=\frac{49}{18000}\left(1.01498 \times 10^{10}\right) e\left(\frac{\sqrt[3]{1.47821 \times 10^{10}}}{24.676}+55.619\right)$

Solving for efficiency gives us $e=80.6310 \%$. Based on our assumption that efficiency is constant, the plant is much more productive when the reservoir is full (as at the end of the high-inflow case) than when it is empty (as in case the low-inflow case). With an outflow of $1.01516 \times 10^{10}$ cubic meters, the plant would generate $3.93125 \times 10^{9} \mathrm{kWh}$ if the reservoir were full but only $1.23869 \times 10^{9} \mathrm{kWh}$ with an empty reservoir (in which case the water would only fall 55.619 meters). In Arizona, where the price of electricity is 10.01 cents per kilowatt-hour, this difference of $2.69256 \times 10^{9} \mathrm{kWh}$ translates to a loss of almost $\$ 270$ million per year.

We can calculate the electricity generated by the plant by multiplying the outflow rate, the efficiency, and the change in gravitational potential energy per cubic meter. We will assume that the outflow rate is $1.01516 \times 10^{10}$ cubic meters per year unless the reservoir is full or empty, in which case the outflow rate will be equal to the inflow rate (if the reservoir is empty) or equal to the inflow rate minus loss to evaporation and seepage (if the reservoir is full).

For the worst-case scenario case, the outflow would be $1.01516 \times 10^{10}$ for $t<3.233$ (before the reservoir is empty) and $5.773 \times 10^{9}$ for $t \geq 3.233$ (after the reservoir is empty). In the second case, $V=0$, so $d=55.619$. Thus, the average annual production of energy is

$\frac{1}{5}\left[\int_{0}^{3.233} \frac{49}{18000}\left(1.01516 \times 10^{10}\right)(0.80631)\left(\frac{\sqrt[3]{V}}{24.676}+55.619\right) d t+\int_{3.233}^{5} \frac{49}{18000}(5.773 \times\right.$ $\left.\left.10^{9}\right)(0.80631)(55.619) d t\right]$. This integral, computed by multiplying the flow rate by the reservoir's height (calculated from the volumes computed by the Runge-Kutta method every 0.001 year), amounts to $2.132 \times 10^{9}$ kilowatt-hours annually.

In the most probable scenario, the reservoir is never empty or full, so the outflow is constant over the interval. Thus, the annual energy production is $\frac{1}{5} \int_{0}^{5} \frac{49}{18000}(1.01516 \times$ $\left.10^{10}\right)(0.80631)\left(\frac{\sqrt[3]{V}}{24.676}+55.619\right) d t=3.631 \times 10^{9} \mathrm{kWh}$.

In the best-case scenario, the outflow is $1.01516 \times 10^{10}$ for $t<1.202$, before the reservoir fills. When the reservoir is full, we have $V=2.6526 \times 10^{10}$ and $\frac{d V}{d t}=2.0278 \times 10^{10}-$ $81.7084 V^{\frac{2}{3}}-0.0230033 V-O(t)=0$, so $O(t)=1.8941 \times 10^{10}$. Furthermore, after 1.202 
years, $d=176.4792$, the maximum possible drop, so the dam generates $\frac{49}{18000}(1.8941 \times$ $\left.10^{10}\right)(0.80631)(176.4792)=7.3371 \times 10^{9} \mathrm{kWh}$ annually. In this scenario, the dam produces 863,994 kilowatts of power, less than its maximum capacity of 1.32 million kilowatts. The total energy produced by the dam in this scenario is $\int_{0}^{1.202} \frac{49}{18000}(1.01516 \times$ $\left.10^{10}\right)(0.80631)\left(\frac{\sqrt[3]{V}}{24.676}+55.619\right) d t+(5-1.202)\left(7.3371 \times 10^{9}\right)=3.432 \times 10^{10} \mathrm{kWh}$, or $6.864 \times 10^{9}$ kilowatt-hours annually.

To determine the effect of a slight change in inflow on electric production, we reexamine the scenario in which inflow is $83.83 \%$ of the historic average - slightly better than the midline prediction. In this case, the average annual energy production is $\frac{1}{5} \int_{0}^{5} \frac{49}{18000}\left(1.01516 \times 10^{10}\right)(0.80631)\left(\frac{\sqrt[3]{V}}{24.676}+55.619\right) d t=3.643 \times 10^{9}$ kilowatt-hours. Thus, unless the reservoir becomes completely full or empty, a small change in inflow produces an even smaller change in the dam's power generation (the two values differ by only $0.3 \%$ ) because the excess water is stored in the dam's reservoir.

\section{Third Model: Addressing the Effect of Colorado River Water on the Regional Agricultural Economy}

\begin{tabular}{|c|c|c|c|c|c|}
\hline & \begin{tabular}{|l|} 
Gross State Product \\
(millions)
\end{tabular} & \begin{tabular}{|l|} 
GSP related to \\
Agriculture
\end{tabular} & \begin{tabular}{|l} 
Agricultural water \\
from river
\end{tabular} & \begin{tabular}{|l} 
Value of the river \\
(millions)
\end{tabular} & $\begin{array}{l}\text { Percent of total } \\
\text { GSP from the River }\end{array}$ \\
\hline Arizona & $\$ 256,364.00$ & $0.80 \%$ & $80.00 \%$ & $\$ 1,649.60$ & $0.64 \%$ \\
\hline Nevada & $\$ 126,503.00$ & $0.18 \%$ & $83.00 \%$ & $\$ 193.39$ & $0.15 \%$ \\
\hline Colorado & $\$ 252,657.00$ & $0.72 \%$ & $90.00 \%$ & $\$ 1,640.70$ & $0.65 \%$ \\
\hline Wyoming & $\$ 37,544.00$ & $1.13 \%$ & $45.65 \%$ & $\$ 194.47$ & $0.52 \%$ \\
\hline New Mexico & $\$ 74,801.00$ & $1.50 \%$ & $77.00 \%$ & $\$ 864.71$ & $1.16 \%$ \\
\hline California & $\$ 1,891,363.00$ & $1.22 \%$ & $12.95 \%$ & $\$ 2,995.59$ & $0.16 \%$ \\
\hline Utah & $\$ 112,941.00$ & $0.49 \%$ & $81.10 \%$ & $\$ 446.86$ & $0.40 \%$ \\
\hline Total & $\$ 2,752,173.00$ & & & $\$ 7,985.32$ & \\
\hline
\end{tabular}

(Table 1. Calculation of GSP due to agricultural uses of Colorado River water in the Lower Basin)

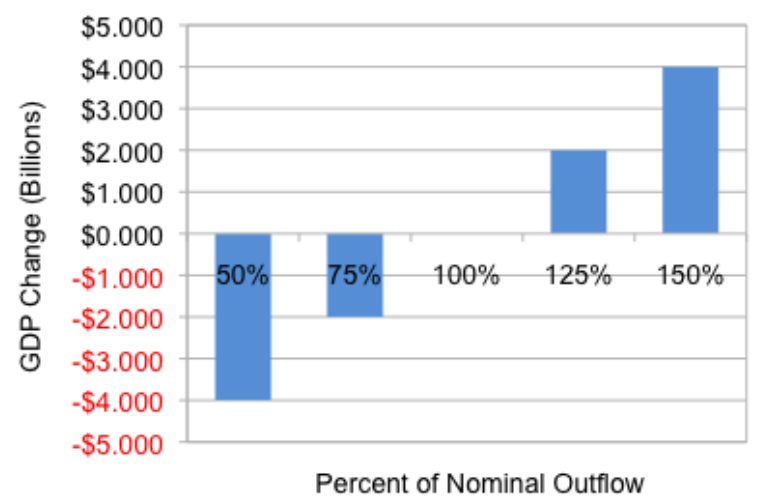

(Figure 3. Effect of water outflow availability from Lake Powell on regional economy)

To analyze the economic impact of the river, we first determine the total GSP (Gross State Product) and GSP due to agriculture $[10,14,16,19]$. From this, we calculate the ratio of 
water used from the river to the total water usage by the states and multiply this fraction by the agricultural GSP for each state to obtain the agricultural GSP based on Colorado River water (see Table 1). If the available water is reduced severely, the national GDP could decrease by billions of dollars. Assuming a linear relationship between water and GDP, we calculate the change in GDP per year for five cases of water availability (see Figure $3)$.

Our analysis highlights the importance of ensuring that there is enough reserve water available to prevent an economic shock to the region in years of drought. In the absence of a reservoir, a lack of water would immediately cause great harm to the Lower Basin's agricultural production and consequentially to its economy.

This prediction is corroborated by the microeconomic principle of derived demand, which holds that the demand for any given factor of production is derived from the demand of the good or service produced. Given that food has an inelastic demand by its very nature (represented in Figure 4 by the nearly vertical line D), the demand for water is very high. Therefore, a reduction in supply (the leftward shift of the line $S$ into $S^{\prime}$ ) as a result of lack of water leads to a much higher price ( $\mathrm{P}^{\prime}$, compared to $\mathrm{P}$ ). Due to the inelastic characteristic of the demand for food, the burden of any increase in the price of food is undertaken almost entirely by the consumers. The high price, according to the substitution effect, would be expected to lead consumers to lower-priced foods, which could be those that are more resistant to drought and less reliant on water. Assuming that prices for these droughttolerant foods remain relatively constant, there would be a loss of revenue in the market for foods that are more water-reliant that would be counted as a loss in the GDP.

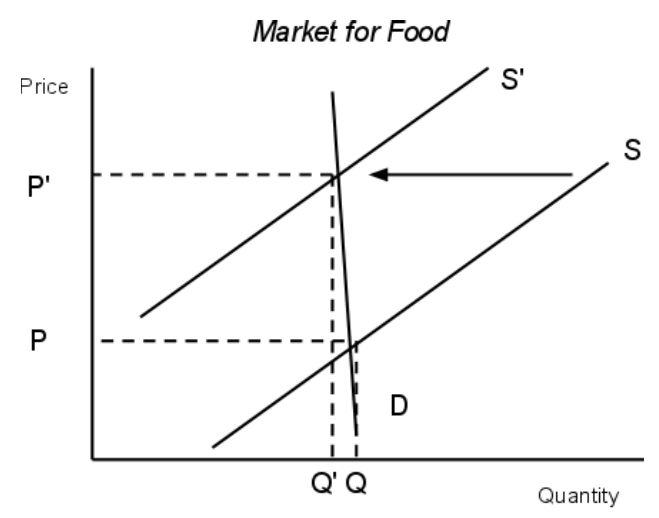

(Figure 4. The effect of a small decrease in food production on food prices)

\section{Recommendations}

We suggest that, due to the importance of a steady flow of water for the economy, the reservoir's content remains large enough that the outflow could be maintained at 8.23 million acre-feet $\left(1.015433 \times 10^{10}\right.$ cubic meters $)$ for two years without the reservoir emptying even if drought limited inflow to $39 \%$ of the historic inflow. In our model of the 
worst-case scenario, the content of the reservoir two years before it dried up is $9.402 \times 10^{9}$ cubic meters. Therefore, we should attempt to maintain the reservoir at a level of at least $9.402 \times 10^{9}$ cubic meters, even if this requires some reductions in water quotas to either the Lower or Upper Basins.

Since approximately $80 \%$ of the outflow from Lake Powell, after evaporation and seepage, is used for agricultural purposes, we recommend cutting down on water consumption in this sector to minimize the total amount of water removed from Lake Powell. To reduce the dependence of farmers on these waters, we offer the following suggestions:

- Minimize reliance on crops that require more water (including rice, produce grown on orchards, and Irish potatoes), and increase harvest of less-water-dependent crops (e.g. soybeans, wheat for grain, and grain sorghum) as listed in Figure 5.

- Use more efficient irrigation systems, including Drip-trickle and Low Energy Precision Application, the efficiency of which is displayed in Figure 6.
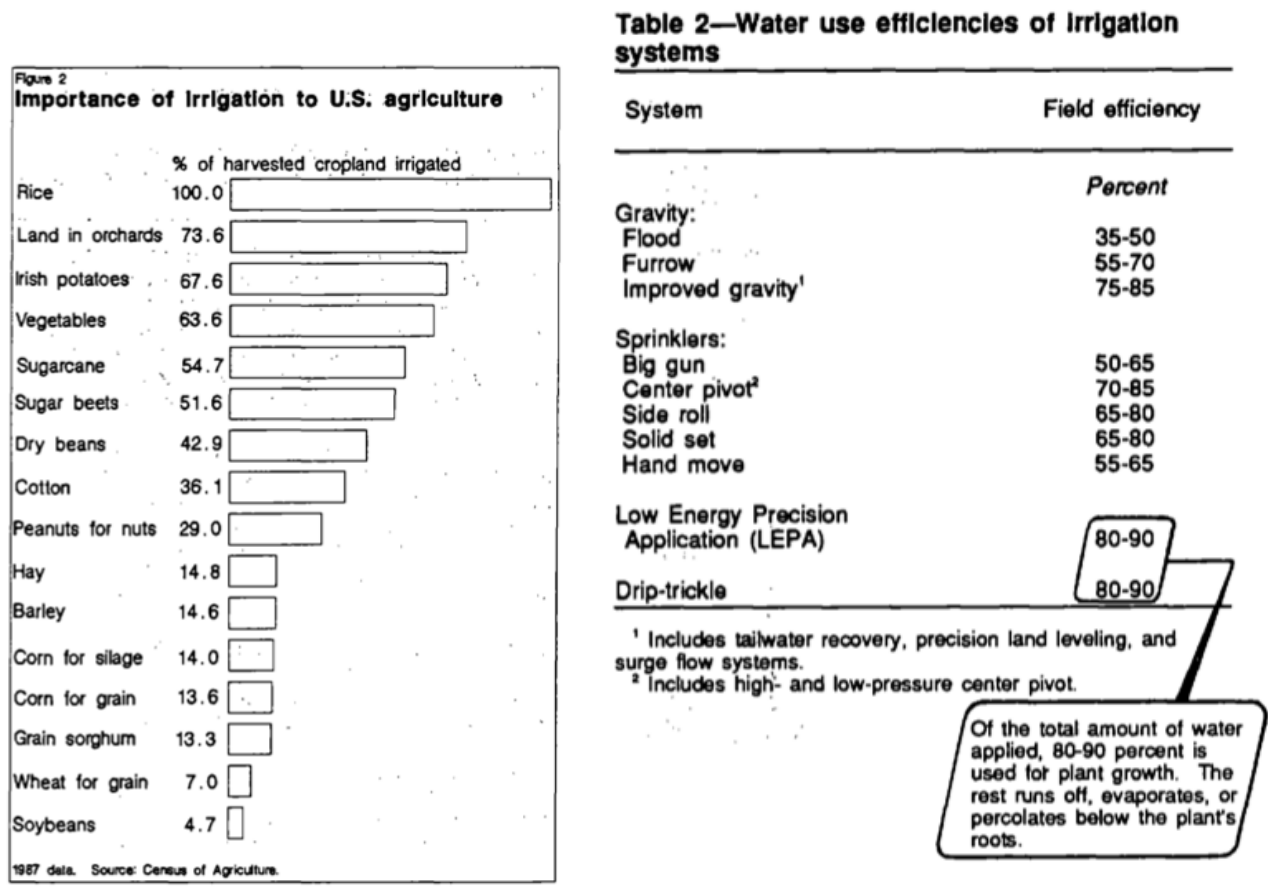

(Figures 5 and 6. Water-use efficiency of principal U.S. crops and irrigation systems) (C) U.S. Department of Agriculture, Economic Research Service. [15]

\section{Conclusion}

The models we developed explain the effects of a prolonged drought on the amount of water in Lake Powell and the economic effects of decreased reservoir volume. Our first model indicates the importance of the water inflow to the lake's volume. The second model expands on this analysis by demonstrating how the water level determines how much water there is for hydroelectric power production. Our third model confirms the Colorado 
River's instrumental role in the agriculture of the Lower Basin and the influence of its availability on the economy of the United States Southwest. 


\section{References}

1. Alles, David L., ed. The Colorado River: An Ecological Case Study in Coupled Human and Natural Systems. Publication. Western Washington University, 24 Feb. 2009. Web. 5 Mar. 2011. <http://fire.biol.wwu.edu/trent/alles/ColoradoRiverIntro.pdf>.

2. Andrews, Phyllis. Colorado River Basin. Digital image. Arizona Dept of Water Resources, Colorado River Mgmt, 5 Mar. 2003. Web. 5 Mar. 2011. <http://eoimages.gsfc.nasa.gov/images/news/NasaNews/ReleaseImages/2003030 5/colorado-river-basin.jpg $>$.

3. "Arizona (AZ) - Census Information." LocalCensus.com Census \& Business Information. LocalCensus. Web. 05 Mar. 2011. <http://www.localcensus.com/state/Arizona>.

4. "Bankstor." Save the Lake. Web. 05 Mar. 2011. <http://www.glencanyon.net/bankstor.htm>.

5. Brown, Glenn O., Jürgen Garbrecht, and Willi H. Hager. “Darcy's Law.” Henry P.G. Darcy and Other Pioneers in Hydraulics. By Henry Darcy. ASCE Publications, 2003. 78-80. Google Books. Google, 26 June 2003. Web. 5 Mar. 2011. <http://books.google.com/books?id=o8ZJ8lFFfnEC\&dq=darcy\%27s+law\&source =gbs_navlinks_s $>$.

6. Bureau of Reclamation. U.S. Department of the Interior, n.d. Web. 5 Mar. 2011. <http://www.usbr.gov/>.

7. Carpenter, Stephen. "Lake Geometry: Implications for Production and Sediment Accretion Rates." Journal of Theoretical Biology 105 (1983): 273-86. University of Notre Dame. Web. 05 Mar. 2011. <http://www.google.com/url?q=http://www.nd.edu/ underc/east/publications/ documents/Carpenter1983.pdf\&sa $=\mathrm{D} \&$ sntz=1\&usg=AFQjCNHz71RUB07WiRyW9SGSi25Uj3inw>.

8. "Colorado River Basin Salinity Control Program - Upper Colorado Region Reclamation." Bureau of Reclamation Homepage. 20 Dec. 2010. Web. 05 Mar. 2011. <http://www.usbr.gov/uc/progact/salinity/>.

9. "Economic Benefits of Lake Powell and the Glen Canyon Dam." Kenyon College Website. Kenyon College. Web. 5 Mar. 2011. <http://www2.kenyon.edu/projects/Dams/gec02ros.html>.

10. "ERS/USDA Data Sets.” USDA Economic Research Service - Home Page. Web. 05 Mar. 2011. <http://www.ers.usda.gov/Data/>.

11. Hill, John William. General Chemistry. Upper Saddle River, NJ: Pearson/Prentice Hall, 2005. Print.

12. "Lake Powell." Utah DEQ: Division of Water Quality. Utah Department of Environmental Quality. Web. 5 Mar. 2011. <http://www.waterquality.utah.gov/watersheds/lakes/LAKEPOWL.pdf>.

13. "Lake Powell and Glen Canyon National Recreation Area." Map. National Park Travel. National Park Travel. Web. 5 Mar. 2011. <http://www.nationalparktravel.com/lakepowell_map.htm>.

14. Owen, Gigi. "Agriculture." Southwest Climate Change Network. Web. 05 Mar. 2011. <http://www.southwestclimatechange.org/impacts/people/agriculture>. 
15. Negri, Donald H.; Hanchar, John J.; and United States Department of Agriculture, Economic Research Service, "Water Conservation Through Irrigation Technology" (1989). All U.S. Government Documents (Utah Regional Depository). Paper 119. $<\mathrm{http}: / /$ digitalcommons.usu.edu/govdocs/119>.

16. "Utah Foundation Research Brief." Utah Foundation. Web. 05 Mar. 2011. <http://www.utahfoundation.org/reports/?page_id=331>.

17. “Water Database." Lake Powell Water Database. 03 Mar. 2011. Web. 05 Mar. 2011. $<$ http://lakepowell.water-data.com/index2.php>.

18. "Water Supply and Lake Powell." Glen Canyon Institute. Glen Canyon Institute. Web. 05 Mar. 2011. <http://www.glencanyon.org/library/water.php>.

19. "Water Use Efficiency." California Department of Water Resources. Web. 05 Mar. 2011. <http://www.water.ca.gov/wateruseefficiency/agricultural/>.

20. Zill, Dennis G. A First Course in Differential Equations with Applications. 4th ed. Boston: PWS-KENT Pub., 1988. Print. 